\title{
Radioecological impact from radionuclide releases into the rivers
}

\author{
I.I. Kryshev, A.I. Kryshev and T.G. Sazykina \\ Institute of Experimental Meteorology of SPA "Typhoon", Lenin Avenue 82, \\ Obninsk, 249038 Kaluga Region, Russia
}

\begin{abstract}
Absract. The radiological impacts from radionuclide releases into Techa, and Yenisei Rivers in Russia are discussed. The dose assessments for human and natural biota are calculated using the methodology of multiple pathways of exposure. In the Mayak complex area the collective dose to the Techa River population during 1949 1956 was 6,200 man-Sv. The collective dose from radioactive discharges of the Krasnoyarsk complex into Yenisei River during the period 1958-199] was about 1,200 man-Sv. A major contributor to this dose was consumption of the fish from Yenisei River (about $70 \%$ ). The doses to the natural biota are considerably higher than those to humans by a factor of 10-1000. This difference is most pronounced in the periods of significant radioactive releases. Especially high levels of exposure to biota were demonstrated for Techa River in the period of maximum discharges of radionuclides. A dose rate level of $10 \mathrm{mGy} /$ day to natural biota was exceeded.
\end{abstract}

\section{INTRODUCTION}

The subject of this report is the estimation of radiological impacts from radionuclide releases into hydrological systems in Russia. For this purpose, the data of radioecological investigations are used in the areas of location of Mayak and Krasnoyarsk complex. The dose assessment for human and natural biota are considered.

Dose assessments were made using the methodology of multiple pathways of exposure, including doses from inhalation, soil, bottom sediments, and consumption of contaminated agricultural and natural products, taking into account recommendations given in [1,2]. Doses to biota were estimated with consideration for geometric characteristics of the organisms and the exposure sources and using the methods described in $[3,4]$. As the input information we used the data of observations and estimated radionuclide concentrations in environmental objects [5-10].

\section{RADIOECOLOGICAL IMPACT FROM DISCHARGES INTO THE TECHA RIVER}

The Techa River is part of the large hydrological system Techa-Iset'-Tobol-Irtysh-Ob' belonging to the Kara Sea basin. The Techa River is $243 \mathrm{~km}$ long, and its catchment area is $7600 \mathrm{~km}^{2}$. The river depth varies from $0.5 \mathrm{~m}$ to $2 \mathrm{~m}$, and its width is, on the average, $15-30 \mathrm{~m}$. The average water flow in the river mouth is about 7 $\mathrm{m}^{3} / \mathrm{s}[7-8]$.

The main sources of radioactive contamination of the Techa River were discharges of radionuclides from Mayak radiochemical complex in the period 1949-1956. In this period, about $10^{17} \mathrm{~Bq}$ of radionuclides entered the river ecosystem, including $1.2 \times 10^{16} \mathrm{~Bq}$ of ${ }^{90} \mathrm{Sr}$ and $1.3 \times 10^{16} \mathrm{~Bq}$ of ${ }^{137} \mathrm{Cs}$. In the period of the most intensive discharges from March 1950 to November 1951, their radionuclide composition (in \%) was the following: ${ }^{89} \mathrm{Sr}-8.8,{ }^{90} \mathrm{Sr}-11.6,{ }^{137} \mathrm{Cs}-12.2,{ }^{95} \mathrm{Zr}$ and ${ }^{95} \mathrm{Nb}-13.6,{ }^{103} \mathrm{Ru}$ and ${ }^{106} \mathrm{Ru}-25.9$, and the other isotopes - 27.9 [7-9].

In November 1951, the discharges of radioactive wastes to the Techa River were reduced considerably because Lake Karachai began to be used for their accumulation. To reduce the radionuclide transport, a system of bypasses and industrial reservoirs for storage of low-activity liquid wastes has been constructed in the upper reaches of the Techa River in the period 1956-1963 [8]. 
By the time of contamination of the river system in 1949, there were 38 settlements with a total population of about 28,000 in the riparian area of the Techa Rjver. Almost all settlements were villages.

The highest radionuclide concentrations in the river water were observed in the period 1950-1951. In 1951, near the village of Muslyumovo at a distance of $78 \mathrm{~km}$ from the site of radioactive discharges, the content of ${ }^{90} \mathrm{Sr}$ in the water was $2.7 \times 10^{4} \mathrm{~Bq} \mathrm{~L} \mathrm{~L}^{-1}$ and that of ${ }^{137} \mathrm{Cs}$ was $7.5 \times 10^{3} \mathrm{~Bq} \mathrm{~L}^{-1}$. Subsequently, the radionuclide activity in the river water decreased considerably [7-9]. By the early $1980 \mathrm{~s}$, the ${ }^{90} \mathrm{Sr}$ concentration in the water had decreased by a factor of $10^{3}$, as compared to that in 1951. In the period 19911998 , the annually averaged content of ${ }^{90} \mathrm{Sr}$ in the water varied between 6 and $20 \mathrm{~Bq} \mathrm{~L}^{-1}$. The annually averaged content of ${ }^{137} \mathrm{Cs}$ in the river water was lower than that of ${ }^{90} \mathrm{~S} r$ approximately by two orders of magnitude. The concentration of ${ }^{239,240} \mathrm{Pu}$ in the river water in this period varied from 0.004 to $0.019 \mathrm{~Bq} \mathrm{~L}^{-1}$. The radioactive contamination of the Techa floodplain is highly nonuniform. The ranges of contamination density of the floodplain are: ${ }^{90} \mathrm{Sr}, 70-6100 \mathrm{kBq} \mathrm{m}^{-2},{ }^{137} \mathrm{Cs}, 30-5600 \mathrm{kBq} \mathrm{m}^{-2} ;{ }^{239240} \mathrm{Pu}, 0.4-4.1 \mathrm{kBq} \mathrm{m}^{-2}[7-9]$. With distance from the river sources, the contamination density of the floodplain decreases, remaining, however, considerably higher than the background values.

The population living on the shore of the Techa River was exposed to increased levels of radiation, both external and internal. The highest dose rates were observed in 1950-1951. The dose accumulation due to external exposure slowed down sharply after 1956, when all population in the upper part of the Techa River was evacuated, and the contaminated floodplain in the other settlements was fenced. The intermal exposure to the population results from the consumption of contaminated local food products and drinking water. The main nuclides responsible for the dose delivery to the population living on the shore of the Techa River are ${ }^{90} \mathrm{Sr}$ and ${ }^{137} \mathrm{Cs}$. The collective dose to 28,000 people, most highly exposed as a result of the Techa River contamination, was about 6,200 man-Sv. The maximum individual doses to humans in the Techa River basin were 2-4 Gy [8-9]. At the present time, the dose rates to the population in the Techa River basin have considerably decreased compared to the maximum exposure levels in 1950-1951 and are about 0.2 $\mathrm{mSv} /$ year.

According to model assessments, the highest doses to aquatic organisms were observed in the upper reaches of the Techa River in the period of maximum discharges of radionuclides (1950-1951). In this period, the internal dose rates in Metlinsky pond were as high as $0.4 \mathrm{~Gy} /$ day for mollusks and 0.09 Gy/day for fish (Table I). The main dose-forming nuclides for mollusks were ${ }^{89,90} \mathrm{Sr}$, ${ }^{106} \mathrm{Ru}$ and ${ }^{144} \mathrm{Ce}$, and for fish ${ }^{89,90} \mathrm{Sr}$ and ${ }^{137} \mathrm{Cs}$. The doses to aquatic biota noticeably decreased with distance from the site of discharges. However, even in the river mouth they were considerably $\left(10^{2}-10^{3}\right.$ times) higher than the natural background. After the cessation of intensive radioactive discharges and the construction of a system of protective water bodies in the upper reaches of the Techa River, the doses to aquatic biota noticeably decreased. It was observed essentially along the whole length of the river, with the exception of industrial water bodies.

Table 1. Internal exposure rate to biota (Gy/day) in the period of maximum radioactive discharges to the Techa River (1950-1951)

\begin{tabular}{|c|c|c|c|}
\hline Organisms & Metlinsky pond & Musluymovo (78 km) & Zatecha (237km) \\
\hline Phytoplankton & 0.01 & 0.004 & 0.0003 \\
\hline Zooplankton & 0.03 & 0.01 & 0.0008 \\
\hline Macrophytes & 0.3 & 0.08 & 0.01 \\
\hline Mollusks & 0.4 & 0.09 & 0.007 \\
\hline Fish & 0.09 & 0.05 & 0.004 \\
\hline
\end{tabular}

Note: The distance from the source of radioactive discharges is given in parentheses.

Table 2. Dose rates to humans (Sv/year) and biota (Gy/year) from radioactive contamination in the Techa River area

\begin{tabular}{|c|c|c|}
\hline Exposed object & $1950-1951$ & $1991-2000$ \\
\hline Humans & $0.1(0.02-4)$ & $2 \times 10^{-2}$ \\
\hline Aquatic biota & 30 & $3 \times 10^{-3}$ \\
Algue & 20 & $2 \times 10^{-2}$ \\
Mollusks & 10 & $4 \times 10^{-3}$ \\
Fish & & \\
\hline
\end{tabular}

The current levels of exposure to aquatic organisms in the Techa River are 3-20 mGy/year (Table 2), i.e. are within the range of "low doses". At the same time, doses to aquatic biota in industrial settling water 
bodies still remain relatively high. For example, doses to fish from incorporated radionuclides in water bodies B-3 and B- 4 may be as high as 5-7 Gy/year. Doses to fish in water body B-10 are somewhat lower and amount to $2-4 \mathrm{~Gy} /$ year [11].

A comparative analysis of doses to the population and biota shows that in all cases, doses to natural biota were considerably (over 10-100 times) higher than doses to humans (Table 2) [6-7,9]. This difference manifested itself most noticeably in the period of increased radioactive discharges in 1950-1951.

\section{RADIOLECOOGICAL IMPACT FROM DISHARGES INTO THE YENISEI RIVER}

The Yenisei is the largest river in the territory of Russia. It runs north-wards and flows into the Yenisei Bay of the Kara Sea. The total length of the river is $4,092 \mathrm{~km}$. Its catchment area is $2,580,000 \mathrm{~km}^{2}$ and the average annual discharge is $591 \mathrm{~km}^{3}$.

Among the sources of river contamination are nuclear reactors, and radiochemical facilities of the Krasnoyarsk mining and chemical industrial complex. Radioactive discharges from the Krasnoyarsk complex contaminate the Yenisei River all the way from the city of Krasnoyarsk to its estuary at a distance of about $2000 \mathrm{~km}$ [10]. In 1992, two of the three nuclear reactors of the Krasnoyarsk complex were removed from service, which reduced considerably the radioactive contamination of the Yenisei River. The total population living on both banks of the Yenisei river downstream of the discharge place is estimated at 340 thousand people.

\subsection{Radioecological modeling of radionuclides migration in the ecosystem of the Yenisei River}

Accumulation of radionuclides by aquatic organisms is a dynamic process governed by both environmental factors and physiological characteristics of aquatic organisms, feeding rate, spectrum of food consumed, position of aquatic organisms in the trophic structure of the ecosystem an so on. The primary mechanisms of radionuclides accumulation by aquatic organisms are bioassimilation (incorporation of radionuclide in internal tissues and organs) and sorption on the surface of aquatic organism.

The dynamics of specific activity of radionuclide accumulated due to bioassimilation in the aquatic organisms can be written as

$$
\frac{d y}{d t}=-\left(\lambda_{r}+\varepsilon_{A} \cdot \frac{W}{M}+\frac{1}{M} \frac{d M}{d t}\right) \cdot y+\frac{Q_{1}^{A}}{Q_{0}^{A}} \cdot\left(\frac{1}{M} \frac{d M}{d t}+\varepsilon_{A} \cdot \frac{W}{M}\right) \cdot X,
$$

where $y$ is the specific activity of radionuclide in aquatic organisms; $\lambda_{p}$ is the radioactive decay constant; $\varepsilon_{\mathrm{A}}$ is a coefficient of proportionality between the elimination rate of the radionuclide and the general rate of metabolism W; $\mathrm{M}$ is the biomass of the aquatic organisms; $Q_{l}{ }^{A}$ is the concentration of stable nutrient in aquatic organism, $Q_{0}{ }^{A}$ is the concentration of stable nutrient in food of aquatic organism or in water, if the aquatic organism accumulates nutrient directly from water; $X$ is the concentration, or specific activity of radionuclide in food of aquatic organism.

This equation (1) can be written for each ecological group of species: phytoplankton, macrophytes, zooplankton, zoobenthos and fish. For correct calculation of radioactive contamination of aquatic organisms, in addition to bioassimilation account should be taken of radionuclides sorption on the surface of aquatic organisms and in a gastrointestinal tract of the fish without further blood absorption. In the present model the processes of sorption and bioassimilation were assumed to be independent of each other.

Fish fauna of the Yenisei River is occurrence of two groups of fish: non-migratory fish traveling over limited distances within tens kilometers from their birth place, and migratory fish which migrate upstream the Yenisei over 400 to $1600 \mathrm{~km}$ from the mouth in the spawning time and spend most of their life time in the delta, inlet or bay which are used by them as feeding areas.

An important feature of the fish fauna of the Yenisei is the presence of long-living fish (both migratory and non-migratory): sterlet, Siberian sturgeon, sea trout, muksun etc., which can accumulate significant concentrations of radionuclides over their lifetime. This makes necessary taking into account the age structure of fish population. In modeling radionuclides accumulation each fish population is 
divided into discrete age classes in such a way that the neighboring age classes differ by 1 year. Each age class is characterized by its own metabolism rate, food consumption rate and relative gain, all these quantities assumed to be identical within each age class [12]. For predatory fish, allowance should also be made for change of diet which usually occurs in the second year of living.

From the radioecological standpoint an important feature of the Yenisei is the low water levels of stable nutrients, particularly phosphorus which is a limiting nutrient for the ecosystem. This may be the reason for increased levels of bioassimilation of radioactive analogues by aquatic organisms. Considering the depletion of the ecosystem in nutrients, the proposed model for radionuclide accumulation by fish assumes that fish is capable of consuming radioactive elements not only with contaminated food by also directly from water.

Let us consider separately the features of radionuclides accumulation by migratory and nonmigratory fish. Using equation (1) we write the equation of the dynamics of radionuclides in non-migratory fish for an averaged fish from the $n$-the age class [12]

$$
\frac{d y_{n}}{d t}=-\left(\lambda_{p}+\varepsilon_{A} \cdot \frac{W_{n}}{M_{n}}+\frac{1}{M_{n}} \frac{d M_{n}}{d t}\right) \cdot y_{n}+\left(\frac{1}{M_{n}} \frac{d M_{n}}{d t}+\varepsilon_{A} \cdot \frac{W_{n}}{M_{n}}\right) \sum_{j} \frac{Q_{1}^{A}}{Q_{0}^{A}} \cdot p_{j} X_{j}(t),
$$

where $\mathrm{y}_{\mathrm{n}}$ is the radionuclide specific activity in fish of the $\mathrm{n}$-th age class; the subscript $j$ applies to the type of food consumed by fish.

For calculating the dynamics of radionuclides in fish of each age class the following characteristics need to be known: Relative change in fish biomass $d M_{n} / d t / M_{n}$; mean fish metabolism rate W/M; specific activity of fish food components $X_{j}$.

Assuming the exponential reduction in the radionuclide activity in the river water as a function of distance from the contamination source, a modification of equation (2) can be written for bioassimilation of radionuclides by migratory fish in the spawning migration period

$$
\frac{d y_{n}}{d t}=-\left(\lambda_{p}+\varepsilon_{A} \cdot \frac{W_{n}}{M_{n}}+\frac{1}{M_{n}} \frac{d M_{n}}{d t}\right) \cdot y_{n}+\left(\frac{1}{M_{n}} \frac{d M_{n}}{d t}+\varepsilon_{A} \cdot \frac{W_{n}}{M_{n}}\right) \cdot \frac{Q_{1}^{A}}{Q_{n 1}^{A}} \cdot C_{0} \cdot \exp \left(-\kappa \cdot\left(L_{m}-v t\right)\right),
$$

where $v$ is the spawning migration speed; $t$ is the time of fish migration from the feeding location to the spawning place, $L_{m}$ is the distance from the contamination source to the fish feeding location, $C_{0}$ is the activity in water near the contamination source, $k$ is the exponent of radionuclide activity reduction in water with distance from the contamination source. Joining of equations (2) and (3) for the feeding and growing period and the spawning period of migratory fish is carried out by specifying the initial conditions for the beginning of spawning migration and return to the feeding areas, respectively. The Yenisei migratory fish have several spawnings in life, but not annually. The interval between spawnings range from 2 years (whitefish) to 5 years (the Siberian sturgeon).

Calculations were carried out for accumulation of ${ }^{32} \mathrm{P}$ by non-migratory fish of the Yenisei as a function of distance from the discharge point. For estimating the specific activity of radionuclides in nonmigratory fish equation (2) was used. It was assumed that the radionuclide enters fish organism directly from water (direct pathway). According to the estimates, the mean annual specific activity of ${ }^{32} \mathbf{P}$ in nonmigratory fish decreases from $3500 \mathrm{~Bq} / \mathrm{kg}$ at a distance of $150 \mathrm{~km}$ from the discharge point to $150 \mathrm{~Bq} / \mathrm{kg}$ at the distance of $1450 \mathrm{~km}$ from the discharge point.

The derived estimates of the ${ }^{32} \mathbf{P}$ concentration factors in non-migratory fish indicate that the concentration factor has pronounced seasonal variations. The maximum ${ }^{32} \mathrm{P}$ contamination levels occur in July-August when the river water is characterized by the highest temperature and exchange processes between fish organism and the environment are most vigorous. At the same time, the concentration of stable phosphorus in river water is decreasing (sometimes to analytical zero), which is also conducive to increase in the ${ }^{32} \mathrm{P}$ concentration factor in fish.

The mean value of the ${ }^{32} \mathrm{P}$ concentration factor in non-migratory fish in the Yenisei is estimated at $2000 \pm 500$, which is consistent with the observational data of the averaged concentration factor in nonmigratory fish from the Yenisei [9]. The highest concentration factors were found for dace, grayling and sterlet, whereas for burbot, on the contrary, much lower concentration factors were reported than for other non-migratory fish. For migratory fish (Siberian sturgeon, pollan) the reported ${ }^{32} \mathrm{P}$ concentration factors were generally an order of magnitude lower than for non-migratory fish. 


\subsection{Dose assessments}

Table 3 presents results of calculating the dose from ${ }^{32} \mathrm{P}$ as a result of consumption of $1 \mathrm{~kg}$ of fish for different sections of the river and the annual radiation doses from ${ }^{32} \mathrm{P}$ as a result of consumption of the Yenisei fish for city dwellers, rural residents and fishermen. The calculation was based on the observational data on ${ }^{32} \mathrm{P}$ fish contamination which were obtained in 1991 [10].

Table 3 Estimated population doses from ${ }^{32} \mathrm{P}$ due to consumption of $1 \mathrm{~kg}$ of fish fom the Yenisei at different distances from discharge locations and the annual dose rates for different population groups, 1991

\begin{tabular}{|c|c|c|c|c|}
\hline $\begin{array}{l}\text { Distance to } \\
\text { discharge } \\
\text { location, km }\end{array}$ & $\begin{array}{c}\text { Type of } \\
\text { population point }\end{array}$ & $\begin{array}{c}\text { Dose from } \\
\text { consumption of } 1 \mathrm{~kg} \\
\text { of fish }\end{array}$ & $\begin{array}{l}\text { Annual dose rate for } \\
\text { population (without } \\
\text { fishermen), mSviyear }\end{array}$ & $\begin{array}{l}\text { Annual dose rate for } \\
\text { fishermen, mSv/year }\end{array}$ \\
\hline-80()$\left.^{\circ}\right)$ & city & 0.0007 & 0.004 & 0.07 \\
\hline 16 & village & 0.0019 & 0.042 & 0.19 \\
\hline 23 & village & 0.0039 & $0 . \overline{086}$ & 0.39 \\
\hline 180 & village & 0.0069 & 0.152 & 0.69 \\
\hline 245 & settlement & 0.0051 & 0.112 & 0.51 \\
\hline 330 & city & 0.0026 & 0.015 & 0.26 \\
\hline 582 & village & 0.0046 & 0.101 & 0.46 \\
\hline 621 & village & 0.0039 & 0.086 & 0.39 \\
\hline 700 & village & 0.0013 & 0.029 & 0.13 \\
\hline 810 & village & 0.0052 & 0.113 & 0.52 \\
\hline 1220 & village & 0.0016 & 0.034 & 0.16 \\
\hline 1360 & village & 0.0004 & 0.009 & 0.035 \\
\hline
\end{tabular}

* $80 \mathrm{~km}$ upstream of the discharge location

The annual collective dose from the discharges of the Krasnoyarsk complex in 1985-1991 is estimated to be 35 man-Sv (Table 4). A major contribution to this dose was due to fish consumption (about $70 \%$ ). External exposure from contaminated floodplain accounted for $17 \%$ of the collective dose. The main radionuclides contributing to the internal dose from fish consumption were ${ }^{32} \mathrm{P},{ }^{24} \mathrm{Na}$, ${ }^{56} \mathrm{Mn}$, and ${ }^{65} \mathrm{Zn}$. A major contribution to the external dose was due to gamma-emitting radionuclides, primarilly ${ }^{137} \mathrm{Cs}$, and ${ }^{69} \mathrm{Co}$. On the whole during the period 1958-1991, the collective dose was about 1,200 man-Sv [9].

Table 4. The estimated collective effective dose from operation of Krasnoyarsk complex in 1985-1991

\begin{tabular}{|c|c|c|}
\hline Exposure pathways & Annual dose, man-Sv & The main radionuclides \\
\hline $\begin{array}{c}\text { Internal exposure } \\
\text { Fish consumption } \\
\text { Bird consumption } \\
\text { Agricultaral } \\
\text { Drinking water }\end{array}$ & $\begin{array}{c}24 \\
2 \\
1,5 \\
1,5\end{array}$ & $\begin{array}{c}{ }^{32} \mathrm{P},{ }^{65} \mathrm{Zn} \\
{ }^{32} \mathrm{P},{ }^{65} \mathrm{Zn} \\
{ }^{90} \mathrm{Sr},{ }^{137} \mathrm{Cs} \\
{ }^{24} \mathrm{Na}_{3}{ }^{32} \mathrm{P}_{,}{ }^{56} \mathrm{Mn}\end{array}$ \\
\hline External exposure & 6 & ${ }^{80} \mathrm{Co},{ }^{137} \mathrm{Cs}$ \\
\hline Total & 35 & \\
\hline
\end{tabular}

Table 5 . The estimated exposure to aquatic biota in the near zone of Krasnoyarsk complex, mGy/day (1991)

\begin{tabular}{|c|c|c|}
\hline & Dose rate & Background \\
\hline Phytoplankton & $0.01-0.1$ & $0.0005-0.002$ \\
\hline Zooplankton & $0.03-0.4$ & $0.001-0.002$ \\
\hline Macrophytes & $1-4.5$ & $0.001-0.01$ \\
\hline Mollusks & $1-2.5$ & $0.002-0.01$ \\
\hline Fish & $0.3-1.6$ & $0.002-0.01$ \\
\hline
\end{tabular}

Table 5 contains the dose rate estimates for aquatic organisms in the near zone of the impact of the Krasnoyarsk complex as comparison natural background. In this area the technogenic doses are considerably higher than natural levels by a factor of 100-1000. For fish natural background is exceeded of a distance of $250 \mathrm{~km}$. 


\section{CONCLUSIONS}

The historical exposure from radionuclide discharges of Mayak complex into to Techa River (1949-1956) was estimated 6,200 man-Sv. The main nuclides responsible for the dose delivery to the Techa population are ${ }^{90} \mathrm{Sr}$ and ${ }^{137} \mathrm{Cs}$. At the present time the dose rates to the human population have decreased by a factor 100 1000 .

According to model assessments, the highest doses (over $10 \mathrm{mGy} /$ day) were received by aquatic organisms in the upper reaches of the Techa River in the period of maximum discharges of radionuclides (1950-1951). The main dose-forming nuclides for mollusks were ${ }^{89,90} \mathrm{Sr},{ }^{106} \mathrm{Ru}$ and ${ }^{144} \mathrm{Ce}$, and for fish ${ }^{89,90} \mathrm{Sr}$ and ${ }^{137} \mathrm{Cs}$. The current levels of exposure to aquatic biota (1991-2000) in the Techa River are 3-20 mGy/year.

The collective dose from radioactive discharges of Krasnoyarsk complex into the Yenisei River (1958-1991) was estimated 1,200 man-Sv. A major contribution to this dose was due to fish consumption. The main radionuclide contributing to the exposure was ${ }^{32} \mathrm{P}$. The absorbed doses for aquatic biota in the near zone of the impact of radioactive discharges were considerably higher than the natural radiation background. At the present time owing to the reduced radioactive discharges, the radioactive contamination of the Yenisei River is decreased considerably.

The dynamic model is developed for description of radionuclide accurnulation in migratory and non-migratory fish in the Yenisei River. Calculations were carried out for accumulation of ${ }^{32} \mathrm{P}$ by fish of the Yenisei as a function of distance from the discharge point. The mean value of the ${ }^{32} \mathrm{P}$ concentration factor in fish in the Yenisei is estimated at $2000 \pm 500$, which is consistent with the observational data.

The doses to natural biota in the contaminated areas are much higher (by a factor 10-1000) than the doses to humans.

\section{Acknowledgments}

The authors are grateful to S.M.Vakulovsky (SPA "Typhoon", Russia) for discussions and valuable comments.

\section{References}

1. ExtemE. Externalities of Energy. Vol.5: Nuclear (European Commission, Brussels-Luxembourg, 1995).

2. International Basic Safety Standarts for Protection Against Ionizing Radiation and for the Safety of Radiation Sources, Safety Series N 115 (IAEA, Vienna, 1996).

3. Effects of Ionizing Radiation on Aquatic Organisms and Ecosystems, Technical Reports Series N 172 (IAEA, Vienna, 1976).

4.Kryshev I.I., Sazykina T.G., Mathematical modelling of radionuclide migration in aquatic ecosystems (Energoatomizdat, Moscow ,1986) (in Russian).

5. Kryshev I.L., Radiochimica Acta 74 (1996)199-202.

6. Kryshev I.I., Romanov G.N., Sazykina T.G., Isaeva L.N., Trabalka J.R., Blaylock B.G., Health Physics 74 (1998) 687-697.

7. Kryshev I.I., Romanov G.N., Chumichev V.B., Sazykina T.G., Isaeva L.N., Ivanitskaya M.V., J. Environ. Radioactivity 38 (1998) 195-209.

8. Severe Radiation Accidents: Consequences and Countermeasures, edited by L.A. Ilyin and V.A. Gubanov (tzdat, Moscow, 2001) (in Russian).

9. Kryshev I.I., Ryazantsev E.P., Ecological Safety of the Nuclear Power Complex of Russia (Izdat, Moscow, 2000) (in Russian).

10. Vakulovsky S.M., Kryshev I.I., Nikitin A.L., Savitsky Yu.V., Malyshev S.V., Tertyshnik E.G., J. Environ. Radioactivity 29 (1995) 225-236.

11. Kryshev 1.I., Sazykina T.G., Radiation Protection Dosimetry 75 (1998)187-191.

12. Kryshev A.I., Ryabov I.N., J. Environ Radioactivity 50 (2000) 221-233. 